\title{
CLASSROOM MANAGEMENT TECHNIQUES FOR TEACHING ENGLISH INCLUSIVELY TO ADHD AND ASD PRIMARY STUDENTS IN VIETNAM
}

\author{
Vu Hai Ha*, Nguyen Nha Uyen \\ Faculty of English Language Teacher Education \\ VNU University of Languages and International Studies \\ Pham Van Dong, Cau Giay, Hanoi, Vietnam
}

Received 25 February 2020

Revised 20 May 2020; Accepted 29 May 2020

\begin{abstract}
Recently included in general education as a compulsory subject since Grade 3, English has established itself in Vietnam as a crucial foreign language for the people to communicate effectively in a globalization era. As a result, English language teaching for primary students has drawn increasing attention from various educators and researchers. However, their studies and teaching practices often overlook students with Attention Deficit Hyperactivity Disorder and Autism Spectrum Disorder (ADHD and ASD) two of the most popular mental disorders in children. In this regard, this mixed-method case study explores the challenges facing, and the solutions the teachers of ADHD and ASD students in Vietnam have been actively drawing on to facilitate their classroom management. After conducting survey questionnaires with 109 English language teachers from 20 cities located in the three regions of Vietnam, the study proceeded with a series of interviews with teachers along with in-class observations. The results indicate that despite these prevailing difficulties, teachers were able to formulate teaching techniques to showcase plenty of innovativeness and versatility in terms of classroom management, despite certain occurrences of potential harmful acts due to the lack of special education training. The discussion could carry useful implications for researchers and teachers working with ADHD and ASD students in Vietnam.
\end{abstract}

Keywords: ADHD, ASD, English language teaching, classroom management, primary education, Vietnam.

\section{Introduction}

The United Nations Children's Fund (UNICEF) stated in its 1989's The United Convention on the Right of the Children that every child, regardless of their backgrounds, should receive access to education. With reference to Vietnam, the Ministry of Education has released Circular No. 03 containing objectives, requirements, and support for children who belong to this group in an inclusive education model (Vietnam's

Corresponding author: Tel.: 84-983536788

Email: haiha.cfl@gmail.com
Ministry of Education and Training, 2018a). Children with special needs due to physical and mental defects are not exceptions, and have the fullest rights to be educated, trained, and supported to maximize their potentials and opportunities to develop themselves and integrate into society (UNICEF, 1989). Unlike impairments that involve bodily and sensory functions, the struggles for children with mental, behavioral, and neurodevelopment disorders are on another level of complexity for the reasons that they are not "tangible". Children with Attention-deficit hyperactivity disorder (ADHD) are one of the most common 
childhood behavioral problems, which accounted for $5 \%$ of the global population on average (Saya, Prasad, Daley, Ford \& Coghill, 2018). Besides, ADHD frequently occurs in conjunction with Autism spectrum disorder (ASD), and clinicians are allowed to diagnose the two disorders (ADHD and ASD) together (American Psychiatric Association, 2013; Antshel, Zhang-James, Wagner, Ledesma \& Faraone, 2016).

However, the new context of English language teaching and learning in Vietnam may pose new challenges to those students. For its importance as a mutual language across countries and global organizations in this globalization era (Brown, 1994), English has recently been included in the formal education in Vietnam as an optional subject since Grade 1 , and become compulsory from Grade 3 to 12. In order to enhance the quality of learning and teaching English in general education, the MOET English curriculum and textbooks have been reformed endorsing the communicative language teaching approach (CLT) to foster learner language acquisition through interpersonal interaction (Vietnam's Ministry of Education and Training, 2018b). Despite being considered as a beneficial approach for students around the age of primary education, CLT may pose certain challenges to ADHD and ASD students, who are disadvantaged by their distinctive behavioral and neurological features. This imposes extra pressure on the primary English teachers, particularly in managing a classroom with ADHD and ASD students among others. To investigate how teachers deal with this actual state, this article aims to answer the research question of: "What classroom management techniques are used by these teachers to facilitate their ADHD and ASD students' learning?"

\section{Literature review}

The definition of classroom management, despite being expressed somewhat differently in terms of word choice, revolves around governing a classroom with proper educational incentives to create an environment friendly for learning (Brophy, 1988; Kayikçi, 2009). Researchers perceive the classroom as a subunit of the school system and emphasize its management as the primordial condition for learning and teaching activities to occur (Marzano, Marzano, \& Pickering, 2003). As a result, the public regarded classroom management as "the answer to many school problems", according to the Gallup poll from 1977 to 1992 (Evertson \& Harris, 1992, p.74). In terms of the components of classroom management, the taxonomy is diverse and characteristic for each particular setting. Nevertheless, regarding elementary education, the discipline in a class mainly covers classroom arrangement, procedures, classroom rules, giving instructions and eliciting techniques, creating a collaborative learning environment, and handling students' behaviors (Evertson, 1994). These aspects are the focus of this study.

Even though classroom management plays such a pivotal role in assuring the efficacy of a lesson, it is exceptionally challenging to a classroom with ADHD and ASD students. According to the American Psychiatric Association (2013), ADHD and ASD often concurrently manifest in young children and are allowed to be co-diagnosed. ADHD and ASD students share mutual symptoms, which are the constant repetition of motor behaviors (running in circles, kicking), low attention span, high sensitivity and irritability (especially in a new environment), and inadequate social skills (Reiersen, Todd, 2008). As a result, managing a classroom with special students who have ADHD and ASD prove to be extremely complicated for teachers (Oliver, Wehby, \& Reschly, 2011).

Teaching ADHD and ASD students should stem from a careful assessment of each individual over a period of time (David \& Floridan, 2004). Understanding of the neurodiversity manifests in strengths, weaknesses, and preferences of the students is vital to customize a well-fit learning approach 
for them (Thunerberg et al, 2013). In summary, a successful inclusive environment by any means should conceive plasticity and diversity as their fundamental principles (UNESCO, 2005, p.16). Despite not suggesting particular teaching approaches for students with ADHD and ASD, experts do recommend certain teaching models or techniques to follow. For example, David and Floridan (2004) summarized three groups of teaching principles that most teaching strategies were related to, namely behavioral model, constructivist model, and ecological model.

The behavioral model directly concentrates on fostering the favorable actions of the students through rewards and using rules as the ground for regulating unwanted behavior. This model holds the belief that students' problems can be "fixed", and this is also recorded to bring visible progress in the students' learning outcomes in a short amount of time.

The constructivist model considers the learner as an active receiver of knowledge and creates a sense of satisfaction when being able to gain new experience through solving problems, participating in activities, and interacting with others.
The ecological model requires students to work as a part of a system, with more attention being paid to the ability to fit in the system of the learner. The ecological approach divides a scale to present different layouts of a system that has impacts on the students. This includes the microsystem (the classroom), with the most direct involvement with students, and other systems on the macro level, representing the cultural, social, industrial and political forces being more subtly enforced on the students. Practices of ecological model primarily focus on the microsystem (classroom) with the incorporation of outdoor activities, change of settings, community work... in order to provide students with the awareness of their roles in the broader system.

Apart from these models, it is advisable for teachers to take into consideration the factors to adapt curricula in order to provide access to both ADHD \& ASD students and other students. To serve this purpose and based on the Instructional and Universal Design, Friends and Bursuck (1999) suggested a recipe for success for an inclusive classroom. This was subsequently adapted by Duvall (2006) for the language classroom, following seven steps denoted in the mnemonic INCLUDE.

Table 1. Seven steps in the successful recipe for language inclusive classrooms

\begin{tabular}{cc}
\hline Code of steps & Main principle \\
\hline $1-\mathrm{I}$ & Identify Classroom Environmental, Curricular, and Instructional Demands \\
$2-\mathrm{N}$ & Note Student Learning Strengths and Needs, \\
$3-\mathrm{C}$ & Check for Potential Areas of Student Success \\
$4-\mathrm{L}$ & Look for Potential Problem Areas \\
$5-\mathrm{U}$ & Use Information Gathered to Brainstorm Instructional Adaptations \\
$6-\mathrm{D}$ & Decide Which Adaptations to Implement \\
$7-\mathrm{E}$ & Evaluate student progress \\
\hline
\end{tabular}

Teachers are often assumed to take up various fundamental duties, such as detecting the children's abnormalities to refer to help and offering support in inclusive classrooms (Vaughn \& Bos, 2015). With respect to an EFL teacher in particular, they also have to fulfill the role of an EFL teacher during their English lesson. As CLT has been proclaimed as the main approach for the English language teaching in the new national curriculum in Vietnam (Vietnam's Ministry of Education and Training, 2018b), the pedagogical demands for 
EFL teachers have become more challenging, especially in terms of the shift from teacheras-conductor to teacher-as-facilitator (Widdowson, 2001). Meanwhile, ADHD and ASD students are often characterized by disruptive behaviors, which lead to conflict during peer-to-peer interactions (Antshel, Zhang-James, Wagner, Ledesma \& Faraone, 2016). Hence, the CLT approach, which relies on classroom interactions for language learning, maybe incompatible with these two groups of students.

Teachers who took part in other research expressed their unavailability due to various reasons, namely the lack of proper training (Blanton, Pugach, \& Florian, 2011), problems arising with students' disruptive behaviors in a classroom context (Barkley, Fischer, Edelbrock, \& Smallish, 1990; DuPaul \& Eckert, 1997, 1998), students' unsatisfied academic outcomes (Marshall, Hynd, Handwerk, \& Hall, 1997; Pfiffner \& Barkley, 1990) and teacher's mental exhaustion (Talmor, Reiter, \& Feigin, 2005). If these problems persist, it could leave a negative influence on the teachers' welfare as well as prompt teachers to conduct incorrect or harmful acts on the students for the sake of managing their classroom. According to Pokrivčáková, S. et al. (2015), these acts may include:

1) Exempting the ADHD and ASD students from the class overall progress or treat them with ignorance for the preconception that their defectiveness would lead to incapability;

2) Overly tolerating the ADHD and ASD students with little intervention to aid students in the subject and general development;

3) Adhering to a fixed teaching approach and leaning toward exclusion of students' personal behavioral patterns or needs;
4) Giving out inappropriate orincompatible tasks or instructions for the ADHD and ASD students (for example, require a dyslexic student to read out loud a long text);

5) Making adjustments to the ADHD and ASD students' mistakes in an insensitive way (announce their mistake in front of the class, compare to other students in a way that make them feel self-deprecated etc.);

6) Accidentally separating the ADHD and ASD students from the class by constantly assigning them different tasks from the rest of the class.

Previous studies consistently indicated that teachers had the tendency to limit imposing their authority on special students due to the lack of proper training in this field and fear of losing time to take care of other students in the class (Emmer \& Stough, 2001; Oliver, Wehby, \& Reschly, 2011). This avoidant attitude resulted in special students' receiving less amount of instruction and facilitation compared to other peers (Gunter, Denny, Jack, Shores, \& Nelson, 1993), and was likely to lead to a general degradation in learning outcomes of the class (Shinn, Ramsey, Walker, Stieber, \& O’Neill, 1987; Cameron, Connor, Morrison, \& Jewkes, 2008). Among classroom management strategies applied to classrooms with ADHD and ASD students, the tactics used to prevent unwanted behaviors were prioritized. To exemplify, preventive approaches such as enacting the class rules or schedules helped to create behavioral imprints to students and served as a framework for determining which actions would be acceptable. Therefore, teachers could refer to that to encourage the appropriate actions and hinder the inappropriate ones (Kameenui, \& Sugai, 1993; Lewis \& Sugai, 1999). Besides, past research claimed that effective classroom management tactics should be derived from 
a collection of individual teachers' methods which were consolidated with personal justifications and classroom observation (Oliver, Wehby, \& Reschly, 2011). Hence, this study aims at exploring English teachers' classroom management strategies applied to their inclusive English classrooms with ADHD and ASD students. This would be a significant contribution to the literature gap by laying the groundwork for empirical research on inclusive classroom practices.

\section{Research method}

This study adopted a case study research design. Traditionally, a case study mainly makes use of a qualitative approach. However, as both a deep and broad understanding of the research problem was the ultimate goal of a case study, mixed methods were applied to enrich the data. The study took place in Vietnam from
2019 to early 2020, when English had just been incorporated as a compulsory subject in formal education starting from Grade 3. This study primarily focused on English language teachers in primary schools of Vietnam, who held the ultimate responsibility for the English language learning of young students.

114 participants partook in the survey in total, with 109 valid responses by 79 English language teachers in public schools and 30 teachers from private schools in 20 major cities situated in three different regions of Vietnam (southern, northern, and the middle regions). Only five English language teachers from private schools had participated in a limited number of short-term training on special needs education. The number of respondents and their locations is presented in Table 2 hereafter.

Table 2. Survey respondents $(\mathrm{N}=109)$

\begin{tabular}{|c|c|}
\hline Location & $\mathrm{n}$ \\
\hline Hanoi (central districts) & 16 \\
\hline Hanoi (others) & 9 \\
\hline Hai Phong & 5 \\
\hline Hai Duong & 2 \\
\hline Thai Nguyen & 2 \\
\hline Bac Ninh & 18 \\
\hline Ha Nam & 6 \\
\hline Nam Dinh & 12 \\
\hline Phu Tho & 2 \\
\hline Ha Giang & 5 \\
\hline Kien Giang & 2 \\
\hline Lao Cai & 1 \\
\hline Thanh Hoa & 2 \\
\hline Hue & 6 \\
\hline Khanh Hoa & 1 \\
\hline Da Nang & 2 \\
\hline Quy Nhon & 1 \\
\hline Quang Tri & 3 \\
\hline Quang Ngai & 1 \\
\hline Can Tho & 1 \\
\hline Ho Chi Minh City & 10 \\
\hline
\end{tabular}


The teachers selected to enter the interview were those exhibiting strong opinions in their questionnaire and had officially recorded students with ADHD and ASD in their classes.
Additionally, to avoid bias, the diversity of locations was taken into consideration. Based on these two main criteria, 20 teachers were selected for the interview round (Table 3 ).

Table 3. Interview participants

\begin{tabular}{ccc}
\hline Code & Specifications \\
\hline Teacher 1 & A teacher with over 20 years of experience, currently teaching in a public school on the \\
outskirt of Hanoi.
\end{tabular}

After being approved by the headmaster of the schools and receiving consent from Teachers 1,2 , and 19, who had confirmed cases of ADHD and ASD students, observations were carried out in their classrooms. The whole process of data collection is summarized in Table 4.

Table 4. Data collection procedure

\begin{tabular}{|c|c|}
\hline $\begin{array}{c}\text { Name of the stages } \\
\text { Stage } 1 \\
\text { Stage } 2 \\
\text { Stage } 3\end{array}$ & $\begin{array}{c}\text { Activities } \\
\text { Pilot survey } \\
\text { The official survey (109 valid responses) } \\
\text { Interviewed } 20 \text { teachers from different locations and } \\
\text { observed four classrooms in various lessons }\end{array}$ \\
\hline $\begin{array}{l}\text { An interview guideline for teachers } \\
\text { vas designed based on the Interpretation of } \\
\text { nstructional and Universal Design (Duvall, } \\
\text { 2006), Understanding SEN (Special Education } \\
\text { Needs) students online course from the British } \\
\text { Council and interview guidelines in the research }\end{array}$ & $\begin{array}{l}\text { conducted by Torres (2016). The guidelines } \\
\text { include four parts: background information, } \\
\text { teacher's opinion on teaching ADHD and ASD } \\
\text { students in an inclusive classroom, teacher's } \\
\text { English classroom management strategies, and } \\
\text { teacher's difficulties in teaching. }\end{array}$ \\
\hline
\end{tabular}


Prior to the interview, the questionnaire was distributed together with the interview invitation to EFL teachers in primary schools to gain an overview of the research problems. The questionnaire consists of four parts presented below:

\section{Part 1: Background information}

This part was adapted based on the original questionnaire Opinion Relative to Mainstreaming ORM Scale (Larrivee \& Cook, 1979; Larrivee, 1982; Antonak \& Larrivee, 1995) and incorporated certain extension from the revision version of the ORM scale, the Teacher Attitude to Inclusion TAIS Scale (Monsen, Ewing \& Boyle, 2015). This part consists of participants' information such as age, gender, years of experience, the number of students in their class and school, and the level of frequency that they have in contact with ADHD and ASD students (ranging from "never" to "frequently").

\section{Part 2: Teachers' attitude on teaching students with $A D H D$ and $A S D$ in an inclusive classroom}

The main content of this part revolves around teachers' attitudes, which are specified into three aspects: teachers' belief, willingness, and difficulties when working with children with behavioral problems. The participants rate their level of agreement to each item by choosing a number on a Likert scale ranging from 1 (Strongly disagree) to 5 (Strongly agree). This part is a synthesis and adaptation of the ORM and its revisions, the TAIS scale by Monsen and Frederickson (2004), the TAIS scale by Saloviita (2015), and an adaptation of ORM made by Avramidis, Bayliss and Burden (2000). There are a number of studies from reputable groups of researchers to testify their validity and reliability (Monsen, Ewing \& Boyle, 2015; Ewing, Monsen \& Kielblock, 2018; Kielblock, 2018). Thus, the original framework and its revised versions are widely used in research relating to teachers' attitudes on the inclusion of children with disabilities and special needs. Because the framework covers all types of special needs students including students with behavioral disorders and different aspects of learning and teaching, the questionnaire was adapted and narrowed down to align with the target of the study. This part has 27 items in total.

\section{Part 3: Teachers' classroom management strategies}

This part is divided into two sub-divisions: teachers' beliefs and classroom management techniques. The items in this part aim at measuring the level of assimilation of an EFL teacher in an inclusive environment, their readability to theMOET's objectives of English for elementary students, and their flexibility in the classroom management strategies they use in an inclusive classroom with ADHD and ASD students. The participants need to choose a number on a Likert scale from 1 to 5 in accordance with their opinion, similarly to Part 2. The items were adapted to suit the research purposes from Duvall's interpretation of Instructional and Universal Design (2001) and the Understanding Students with Special Educational Needs course online of the British Council.

The quantitative data collected were analyzed using descriptive methods while qualitative data analysis drew on thematic analysis. These results are presented in the following discussion. 


\section{Findings and discussion}

Table 5. Classroom management techniques in an English inclusive classroom

\begin{tabular}{|c|c|c|c|c|c|c|c|c|}
\hline Items & $\begin{array}{l}\text { Strongly } \\
\text { disagree }\end{array}$ & Disagree & Uncertain & Agree & $\begin{array}{c}\text { Strongly } \\
\text { agree }\end{array}$ & Mean & Mode & SD \\
\hline $\begin{array}{c}\text { 5.1 I arrange the classroom } \\
\text { to make it a safe and } \\
\text { accessible place }\end{array}$ & $5.50 \%$ & $1.83 \%$ & $13.76 \%$ & $62.39 \%$ & $16.51 \%$ & 3.8 & 4 & 0.92 \\
\hline $\begin{array}{l}\text { 5.2 I only need my ADHD } \\
\text { and ASD students to obey } \\
\text { my commands. }\end{array}$ & $8.26 \%$ & $20.18 \%$ & $49.54 \%$ & $17.43 \%$ & $4.59 \%$ & 2.9 & 3 & 0.94 \\
\hline $\begin{array}{l}5.3 \text { I make deductions about } \\
\text { the potential problems that } \\
\text { the ADHD and ASD students } \\
\text { might face in my class. }\end{array}$ & $2.75 \%$ & $4.59 \%$ & $31.19 \%$ & $55.96 \%$ & $5.50 \%$ & 3.6 & 4 & 0.79 \\
\hline $\begin{array}{l}5.4 \mathrm{I} \text { encourage them to } \\
\text { engage in social interactions } \\
\text { with peers through group } \\
\text { work and discussion. }\end{array}$ & $3.67 \%$ & $1.83 \%$ & $6.42 \%$ & $68.81 \%$ & $19.27 \%$ & 4.0 & 4 & 0.82 \\
\hline $\begin{array}{l}5.5 \text { I allow ADHD and ASD } \\
\text { students to behave in their } \\
\text { own way in condition that } \\
\text { those behaviors would not } \\
\text { disrupt the class. }\end{array}$ & $3.67 \%$ & $2.75 \%$ & $16.51 \%$ & $63.30 \%$ & $13.76 \%$ & 3.8 & 4 & 0.84 \\
\hline
\end{tabular}

Generally, English teachers acknowledged ADHD and ASD students' behavioral patterns and did not force them to act like other students of the classes on every occasion, with approximately $77.06 \%$ of the total responses for Item 5.5, Table 5 ranging from "agree" to "strongly agree". In order to create a safe, friendly, and supportive learning environment, classroom arrangement and collaborative activities were the two other factors that received attention from the English teachers, with a similarly high level of agreement with Items 5.1, 5.3, and 5.4. The reasons behind these trends will be elaborated with the help of qualitative data in turn as follows:

\subsection{Physical classroom arrangement}

When asked about class management techniques, the teachers highlighted the seating organization in class. They generally attempted to organize the class to ensure maximum safety and flexibility for primary students at the age from six to eleven. This age group were not fully aware of the physical risks around and could easily hurt themselves. Extra guidance and actions were also taken for the needs of ADHD and ASD students, with the majority (78.9\%) choosing "agree" to "strongly agree" with the statement. As for their seating in the class, a preferred place for them was in the first or second front row within or near the action zone of the teachers. Some teachers elaborated:

I often place them in the first or second row, near the board where I usually stand, even though they prefer to sit at the end of the class to freely pick up at their friends. When they sit near the teachers, their manners are improved, and they are also more attentive to the lesson. (Teacher 2)

Sometimes the homeroom teacher is in charge of assigning fixed seating for each 
student, and the English teachers retain that arrangement in our class. If the homeroom teacher is considerate and thoughtful, they will let these special students sit at the front to take care of them better. However, there are also teachers who regard these students as a nuisance, so they will put them further in the back then neglect their existence. (Teacher 5) They can be arranged either in the back or the front. It depends on the teacher's preference. (Teacher 11)

When ADHD and ASD students were seated closer to the teacher, it was easier for the teachers to observe these students' behaviors and interfered immediately when unwanted incidents occurred. Furthermore, plenty of studies have highlighted the benefits students could reap from staying in teachers' action zone. Specifically, a close-distance contact with the teachers would facilitate them in drawing the special students' attention and engage them in the lesson (Jones, 1989; Ford, Olmi, Edwards, \& Tingstrom, 2001; Bohlin, Durwin, \& Reese-Weber, 2008). For ADHD and ASD students, who are characterized by distractibility, overreaction, and recklessness, it is even more crucial for them to stay under the teacher's influence.

Although previous studies had stressed challenges ADHD and ASD students had to face in interpersonal interactions among themselves and other peers in classrooms (Barkley, Fischer, Edelbrock, \& Smallish, 1990; DuPaul \& Eckert, 1997, 1998), 88\% of the teachers participating in this study advocated establishing social relationships to foster special students' good manners. For example, Teacher 14 would form a pair of special one next to a neighbor with the opposite personality, so the special student could have not only a friend but also a role model to learn after.
In a classroom with ADHD and ASD students, it was of critical necessity to set up a corner inside or outside (but near) the class, called the "tranquil corner". This served as a place where children could go and had some time alone to pull themselves together. Other students could also use this place whenever they felt distressed about what happened in the class, or the lesson reached a point that was too overwhelming for them. As reported by Teacher 4, 5, and 17, in several private schools, a consulting room was normally placed near the classroom, so the special students could be escorted there and spent time with the experts until they could calm down and felt ready to go back in class. However, this service was only available if their parents agreed to pay extra fees.

\subsection{Classroom regulation system}

Following the model summarized in the meta-study conducted by David and Floridan (2004), the earliest teaching approach for young special students was the behavioral model. In this model, a system of punishmentand-rewards was applied to consolidate appropriate behaviors and restrict the unwarranted ones. According to Lewis and Sugai (1999), a system of classroom rules was one of the highly recommended preventive strategies for classrooms with behavioral problematic students. In line with this, English language teachers perceived the mechanism of this model as a fundamental factor to regulate a classroom with ADHD and ASD students effectively. While ADHD and ASD students were often known for posing extra needs on the operation of a language classroom, a cohesive and consistent regulation system was reported to be exponentially useful in alleviating the stress in classroom management and create a healthy learning routine for the class. Classroom regulation normally consisted of the following components: 
1. Tasks to do before class: arrange the seating, picking up trash, clean the board.

2. Commands during class time: sit nicely (students have to sit nicely with their back straight and their hands on the table), work in the group of ... (students have to form a group with the number of members accordingly).

3. Permissions to go out during class time with specific sentence samples in English: May I go out to drink water, please? May I go to the toilet, please? (students have to ask the teachers in English when they want to leave the classroom temporarily for personal reasons).

4. Tasks to do after class: might be similar to the tasks before class.

This list of rules would be written out and pinned on an observable wall in class, and repeated before every lesson. Several teachers followed their own styles to encourage the students to conform with the rules, such as giving the students/groups who did their job well with a sticker, star or a smiley face. Also highlighted was a bonus scheme (each requirement met by the student would earn one bonus point, which was represented by a star, sticker and the like), where the bonus point could be exchanged into rewards (treats, or applause from the class, etc.). Teachers highlighted outstanding positive outcomes they observed after a period of time they strictly applied the regulation or bonus point system to their classrooms:

To prevent students' disruptive behaviors, a system of classroom's regulation which is clearly clarified and repeated is the key. (Teacher 13)

My class rarely suffers from the special students' impulsivity, because I tend to be serious and consistent in enforcing classroom rules. For example, if students want to leave their seats or leave the classroom, they need to ask for permission first. It is not advisable for being too harsh on the students; however, we should remind students of the class's disciplines. (Teacher 5)[d1] [WU2]

I reinforce students' memory of the class's rules with proper repetition at the beginning of the lesson. Recently, I give each student a bonus point whenever they comply with the rules, which can be exchanged into snacks or small gifts. Both the special students and others become more obedient, attentive, and active to get the rewards. Because students' level of participation is now measurable, the teacher can keep track of the special ones' involvement in the lesson and take action if they are too inactive. (Teacher 15)

Seven interviewees who applied this system claimed that not only the class ran more smoothly than before, but also the special students' attitude towards learning had been significantly improved. These interviewees also recommended applying a class regulation system as an effective solution to prevent disruptive behaviors of the ADHD and ASD students and reinforce their correct behaviors. One of the teachers even highlighted another benefit of this system by stating that the system facilitated teachers in governing the class as a whole and ensured that "no children were left behind". Based on the number of points each individual or each group had, they could detect the inactive students in class and motivate them to participate more.

\subsection{Buddy system}

From Table 5, Item 5.4, how to create a collaborative learning environment for ADHD and ASD students, who particularly struggled with social interactions, was one of the teachers' major concerns. Buddy system was an innovative classroom management strategy to address this issue as well as compensate for the lack of additional 
support of professionals and teaching assistants. Standing in stark contrast with the precedent investigation, which emphasizes ADHD and ASD's inability to form and maintain a relationship with their peers due to the underdevelopment of social skills and disorderly manner (Barkley, 1998; Kellner, Houghton, \& Douglas, 2003), teachers were strongly rooting for the effectiveness of buddy system. It had an exceptionally high number of advocators, with 19/20 teachers who expressed their preference for it during the interview. In this system, a (more) mature and proficient student was assigned to work in a partnership with the ADHD and ASD ones. This "little mentor" could replace the teachers' role in instructing, correcting, and answering detailed problems of the special student, which was rather time-consuming and impossible to conduct by the teacher alone under such limited time. The teachers could use their spare time to check on these pairs' progress and guide them on a more general level. In fact, Teacher 2 even reported, "Some of the primary students were more mature than we thought. They could instruct their peers with dedication like a teacher and took care of them like older siblings".

When concern was expressed regarding the mentors' willingness to support their peers, 16/20 teachers claimed that "it was not an issue". In fact, the mentor would be eager to help after being incentivized.

If I arrange the more competent student into a pair or group which has special ones, I would encourage that pair/group with a bonus point if they can reach a goal that I have specially designed for them. This motivates the more proficient student to put effort into supporting the weaker ones, hence, all members in the pair/group have a favorable learning outcome after the activity ends. (Teacher 19)
Drawing on the mentors' preference to be treated as adults, the teachers praised them for being "grown-up" when they successfully help the special students. Furthermore, bonus points were also granted for the pair if they could complete a given task together. With the mentioned incentives, rarely any case where the mentor refused to cooperate was reported.

Teachers 5, 8, 13, and 19 even flexibly combined both the buddy system with the bonus point system to synergize the strengths of both regimes. When assigning collaborative activities, they would arrange mixed-ability groups with a competent student as the group leader and one or two special students. The group leader then followed the teacher's instructions to guide the special ones to complete tasks that were intriguing and simple for them, and the whole group would get bonus points for successfully supporting each other to reach both individual and mutual goals. Former explorations had stated that ADHD and ASD students were capable of completing tasks equal to their level and could be stimulated by meaningful and thought-provoking activities (Greene, 1995; Zentall, 1993; DuPaul \& Power, 2000).

However, this strategy was not always effective, especially to inactive special students. From the the classroom observation, the three teachers $(1,2$, and 19) generally neglected the inactive special students, leaving them silent in group work and pair work. Based on the list of the harmful teacher' acts by Pokrivčáková, S. et al. (2015), this might be one of the most potentially prevalent ones. However, 16/20 teachers who highly recommended this model claimed that even though the children remained passive compared to other peers in a group or a pair, their spirit was lightened up over time and they displayed a positive attitude towards learning at the end of the semester. 


\subsection{Resolving interpersonal conflicts}

Interpersonal conflicts were part of teaching to ADHD and ASD children, especially in a subject that relied on an interactive and communicative approach like English. Children with ADHD and ASD often had a volatile temperament, controlling manner, and extreme reactions (Erhardt \& Hinshaw, 1994; Hinshaw \& Melnick, 1995). They could be oblivious to social cues, a pivotal skill to maintain mutual understanding with their classmates (Atkinson, Robinson, \& Shute, 1997). In a similar vein, 20/20 teachers confirmed the manifestation of these problematic traits in their special students. ADHD and ASD students tend to be vulnerable and susceptible to stimulants which possibly caused stress, so to maintain a stable and pleasant environment for them to study in was critical.

Fortunately, their classmates tended to express their sympathy with the special students, according to the teachers' observation. They might quarrel because of trivial affairs but would forgive each other soon later. In a broader sense, most previous studies that examine the problems in a bilingual inclusive classroom did not record the interpersonal relationship between ADHD and ASD students and other peers in class as a significant difficulty. In a study conducted by Pandurean (2014), most students in an inclusive classroom were willing to work with their ADHD and ASD peers.

To restrict the risk of collision in class, the teachers paid great attention to the class and attempted their best to devoid their class of any abusive circumstances together with lecturing the students about tolerance and affection towards those who were different. Nonetheless, the teachers asserted that they would not lavish the special children with bias, but preferred to resolve the problems rationally. To exemplify, if a special student and another peer got into a fight, the teacher would explicate the situation for both of them to understand and demand the one at fault to apologize to the other. They stressed that the impartiality in dealing with such situations would eventually adjust the behavior and consolidate the rightful manner of both the special and other students.

However, in reality, some teachers could be perplexed when encountering conflicts among special and other students. For example, during a lesson of Teacher 1, a student got into a fight with a special tablemate, then repeatedly accused the special student of pulling her hair. Teacher 1 showed signs of avoidance and attempted to buy time so that the homeroom teacher could handle the situation thereafter.

\subsection{Other techniques}

Apart from the aforementioned strategies, versatility was the element needed to adapt to each unique case of ADHD and ASD students effectively. By inspecting the personality traits of the special students, teachers could discover novel techniques to explore new potentials in the students.

After a while teaching an ADHD and ASD child in my class, I realized he/she was deeply affectionate to his/her mother and was deadly afraid of doing anything that might bother him/her. Understanding that, whenever he/she did something wrong, other than simply explain to him/her that was wrong, I also mentioned his/her mother's discontent when knowing it. $\mathrm{He} /$ she never repeated the undesirable behavior afterward. (Teacher 7)

Another feature to notify was that ADHD and ASD students could be exceptionally 
sensitive. According to Teacher 13 and Teacher 20 , they could detect the change in teachers' nonverbal signals, such as the variation in the voice, intonation, body gestures or eye movements. Therefore, teachers could purposefully send the signals to their special students if they were about to conduct a mischievous deed, encourage them to open up or strengthen the bond between them and their teachers. This could help teachers avoid putting off their task in the middle of a lesson to tackle the student. However, 16/20 teachers reported that from time to time they had to deal with extreme cases, where students were so stubborn that they turned down nearly every technique that was applied to govern their behaviors. English teachers from a few private schools which had an apartment for students with special needs could receive support from specialized teaching assistants; however, the collaboration of special students' parents was of crucial necessity to most teachers.

Handling an English inclusive classroom with ADHD and ASD students is extremely challenging; however, the teacher had devised different techniques with great flexibility and creativity. Concerning a more general approach, all the teachers participating in the interview session stated that it was advisable to draw attention to two criteria in order to design an effective classroom management regime: 1) Consider special students' characteristics and 2) Reinforce special students' self-esteem. As for the first principle, this is what the teacher should be mindful of, especially when enacting a classroom's regulation system. The classroom of Teacher 13 which had a student diagnosed with ASD could be a case in point. The children were required to "sit nicely" facing the teacher, but this student preferred to turn his back to the teacher and stared at the wall in the back of the class instead. Although the teacher had repetitively reminded him not to do so, he proceeded with this action. In this case, despite the students' violation of the class's rules, the teacher should be considerate and gradually adjust his behavior in lieu of forcing him to change immediately. According to Teacher 13, "He still learns English quite well in that position, he only does so to feel secure. It is best for him to sit like other students but I do not regard his current posture as some taboo, the prejudice that teachers would hold if they were in my place." Turning to the second principle, $20 / 20$ teachers gave priority to consolidating students' confidence via various means. Teacher 19 provided a realization of this principle by calling ADHD students, who could not stand being immobile, to be a part of the demo session before each activity incorporated in the lesson. The sense of achievement they got from serving themselves as role models for other students would be beneficial for their self-confidence. These two principles embraced INCLUDE by Friends and Bursuck (1999) and Duvall (2006), which also promotes student-centeredness.

\section{Conclusion}

Despite certain limitations in terms of scope, data size, and certain practical issues, this study has shed light on the classroom management in inclusive classrooms that have ADHD and ASD students, calling for increased awareness of their needs and difficulties. By foregrounding five groups of classroom management techniques, the study could bring a general understanding of the teachers' challenges when handling ADHD and ASD students within the context of Vietnam primary schools. Many of those issues call for the cooperation of these four stakeholders PETS: Parents - Experts Teachers - School to facilitate their English language learning inclusively. Regarding 
classroom management, the teachers proposed two systems that were deemed helpful for establishing a constructive classroom, namely the classroom regulation system and the buddy system. The former aligns well with past research, as behavioral models had been traditionally applied to adjusting ADHD and ASD children's behavior. However, the latter seemed to contradict previous examinations on the ground that ADHD and ASD students encountered enormous difficulties in forming relationships with classmates. Although the suggestions were personal and not flawless, teachers could reap the benefits from both the behavioral and collaborative approaches or utilize them in combination with their own versatility and perspicacity. Besides the aforementioned regimes that could serve as valuable references, the study also formulated two principles teachers should take into account when devising classroom management strategies, which are: 1) Consider special students' characteristics and 2) Reinforce special students' selfesteem. Apart from strategies to aid teachers in classroom management, the study also pointed out potential harmful teachers' acts that deserve more attention in the subsequent examinations. From the findings presented, future research could delve further into the measures to form a strong association of PETS, the solutions to undesirable teachers' behaviors to ADHD and ASD students, or the research to testify the effectiveness of these proposed classroom management techniques.

\section{References}

American Psychiatric Association. (2013). Diagnostic and Statistical Manual of Mental Disorders (5th ed.). doi: appi.books.9780890425596

Antonak, R. F., \& Larrivee, B. (1995). Psychometric analysis and revision of the opinions relative to mainstreaming scale. Exceptional Children, 62(2), 139-149.

Antshel, K. M., Zhang-James, Y., Wagner, K. E.,
Ledesma, A., \& Faraone, S. V. (2016). An update on the comorbidity of ADHD and ASD: a focus on clinical management. Expert Review of Neurotherapeutics, 16(3), 279-293.

Atkinson, I. M., Robinson, J. A., \& Shute, R. H. (1997). Between a rock and a hard place: An Australian perspective on education of children with ADHD Educational and Child Psychology, 14, 21-30.

Avramidis, E., Bayliss, P., \& Burden, R. (2000). A survey into mainstream teachers' attitudes towards the inclusion of children with special educational needs in the ordinary school in one local education authority. Educational Psychology, 20(2), 191-211.

Barkley, R. A., Fischer, M., Edelbrock, C. S., \& Smallish, L. (1990). The adolescent outcome of hyperactive children diagnosed by research criteria: I. An 8-year prospective follow-up study. Journal of the American Academy of Child and Adolescent Psychiatry, 29, 546-557.

Blanton, L. P., Pugach, M. C., \& Florian, L. (2011). Preparing general education teachers to improve outcomes for students with disabilities. Washington, D.C.: American Association of Colleges for Teacher Education \& National Center for Learning and Disabilities. Retrieved from http://www.ncld. org/wp-content/uploads/2014/11/aacte_ncld_ recommendation.pdf

Bohlin, L., Durwin, C. C., \& Reese-Weber, M. (2008). EdPsych: Modules. McGraw-Hill Higher Education.

British Council. (n.d). Unit 3 - Differentiation. In Understanding Special Educational Needs (SEN) Online course. Retrieved from https:// teachingenglish.english.britishcouncil.org/Student/ MyCourse.aspx?ID=a2a586a7-d52d-4f62-b2971e0c87c7364e\&ProgramID=aa38bd2b-4c74-49beb815-4a634c781c96

Brophy, J. (1988). Educating teachers about managing classrooms and students. Teaching and Teacher Education, 4(1), 1-18.

Brown, H. D. (1994). Principles of Language Learning and Teaching. Englewood Cliffs, NJ: Prentice Hall Regents.

Cameron, C. E., Connor, C. M., Morrison, F. J., \& Jewkes, A. M. (2008). Effects of classroom organization on letter-word reading in first grade. Journal of School Psychology, 46(2), 173-192.

Colvin, G., Kameenui, E. J., \& Sugai, G. (1993). Schoolwide and classroom management: Reconceptualizing the integration and management of students with behavior problems in general education. Education and Treatment of Children, 16(4), 361-381.

Davis, P., \& Florian, L. (2004). Teaching Strategies and Approaches for Pupils with Special Educational Needs: a Scoping Study. Annesley, Nottingham: DfES Publications.

de Valenzuela, J. S., Bird, E. K. R., Parkington, K., 
Mirenda, P., Cain, K., MacLeod, A. A., \& Segers, E. (2016). Access to opportunities for bilingualism for individuals with developmental disabilities: Key informant interviews. Journal of Communication Disorders, 63, 32-46.

DuPaul, G. J., \& Eckert, T. L. (1997). The effects of school-based interventions for attention deficit hyperactivity disorder: A meta-analysis. School Psychology Review, 26, 5-27.

DuPaul, G. J., \& Eckert, T. L. (1998). Academic interventions for students with attention deficit/ hyperactivity disorder: A review of the literature. Reading \& Writing Quarterly, 14, 59-82.

DuPaul, G. J., \& Power, T. J. (2000). Educational interventions for students with attention-deficit disorders. In T.E. Brown (Ed.), Attentiondeficit disorders and comorbidities in children, adolescents, and adults (pp. 607-635). Washington, DC: American Psychiatric Press.

DuPaul, G. J., \& Stoner, G. (2003). ADHD in the schools: Assessment and intervention strategies (2nd ed.). New York: Guilford.

Duvall, E. D. (2006). Including Students with Disabilities in a Foreign Language Class. TEACHING Exceptional Children, 38(6), 42-48. doi:10.1177/004005990603800606

Emmer, E. T., \& Stough, L. M. (2001). Classroom management: A critical part of educational psychology, with implications for teacher education. Educational Psychologist, 36(2), 103-112.

Erhardt, D., \& Hinshaw, S. P. (1994). Initial sociometric impressions of ADHD and comparison boys: Predictors from social behaviors and non-behavioral variables. Journal of Consulting and Clinical Psychology, 62, 833-842.

Evertson, C. M. (1994). Classroom Management for Elementary Teachers. Allyn \& Bacon, A Division of Simon \& Schuster, Inc., 160 Gould Street, Needham Heights, MA 02194.

Evertson, C. M., \& Harris, A. H. (1992). What we know about managing classrooms. Educational Leadership, 49(7), 74-78.

Ewing, D. L., Monsen, J. J., \& Kielblock, S. (2018). Teachers' attitudes towards inclusive education: a critical review of published questionnaires. Educational Psychology in Practice, 34(2), 150165.

Ford, A. D., Olmi, D. J., Edwards, R. P., \& Tingstrom, D. H. (2001). The sequential introduction of compliance training components with elementaryaged children in general education classroom settings. School Psychology Quarterly, 16(2), 142.

Greene, R. W. (1995). Students with ADHD in school classrooms: Teacher factors related to compatibility, assessment, and intervention. School Psychology Review, 24, 81-93.

Gunter, P. L., Denny, R. K., Jack, S. L., Shores, R.
E., \& Nelson, C. M. (1993). Aversive stimuli in academic interactions between students with serious emotional disturbance and their teachers. Behavioral Disorders, 18(4), 265-274.

Jones, M. G. (1989). T-Zone, Target Students and Science Classroom Interactions, presented at the Association of National for Research in Science Teaching Annual Meeting, Francisco, 31 March 1989. Retrieved from https://eric.ed.gov/?id=ED305258.

Kayıkçı, K. (2009). The effect of classroom management skills of elementary school teachers on undesirable discipline behaviour of students. Procedia-Social and Behavioral Sciences, 1(1), 1215-1225.

Kellner, R., Houghton, S., \& Douglas, G. (2003). Peer-related personal experiences of children with attention-deficit/hyperactivity disorder with and without comorbid learning disabilities. International Journal of Disability, Development, and Education, 50, 119-136.

Kielblock, S. (2018). Inclusive Education for All: Development of an Instrument to Measure the Teachers' Attitudes (Doctoral dissertation, Justus Liebig University Giessen).

Larrivee, B. (1982). Factors underlying regular classroom teachers' attitude toward mainstreaming. Psychology in the Schools, 19(3), 374-379.

Larrivee, B., \& Cook, L. (1979). Mainstreaming: a Study of the Variables Affecting Teacher Attitude. The Journal of Special Education, 13(3), 315-324. doi:10.1177/002246697901300310

Lewis, T. J., \& Sugai, G. (1999). Effective behavior support: A systems approach to proactive schoolwide management. Focus on Exceptional Children, 31(6), 1.

Marinova-Todd, S. H., Colozzo, P., Mirenda, P., Stahl, H., Bird, E. K. R., Parkington, K., ... \& Genesee, F. (2016). Professional practices and opinions about services available to bilingual children with developmental disabilities: An international study. Journal of Communication Disorders, 63, 47-62.

Marshall, R. M., Hynd, R. M., Handwerk, M. J., \& Hall, J. (1997). Academic underachievement in ADHD subtypes. Journal of Learning Disabilities, 30, 635-644.

Marzano, R. J., Marzano, J. S., \& Pickering, D. (2003). Classroom management that works: Researchbased strategies for every teacher. ASCD.

Monsen, J. J., \& Frederickson, N. (2004). Teachers' attitudes towards mainstreaming and their pupils' perceptions of their classroom learning environment. Learning Environments Research, 7(2), 129-142.

Monsen, J. J., Ewing, D. L., \& Boyle, J. (2015). Psychometric properties of the revised teachers' attitude toward inclusion scale. International Journal of School \& Educational Psychology, 3(1), 64-71.

Oliver, R. M., Wehby, J. H., \& Reschly, D. J. (2011). Teacher classroom management practices: Effects 
on disruptive or aggressive student behavior. Campbell Systematic Reviews, 7(1), 1-55.

Pandurean, A. N. (2014). Teaching English Language to Children with Special Educational Needs. TEM Journal, 3(4). Retrieved from https://www.academia. edu/9624919/Teaching_English_Language_to_ Children_with_Special_Educational_Needs

Pesco, D., MacLeod, A. A., Bird, E. K. R., Cleave, P., Trudeau, N., de Valenzuela, J. S., ... \& Segers, E. (2016). A multi-site review of policies affecting opportunities for children with developmental disabilities to become bilingual. Journal of Communication Disorders, 63, 15-31.

Pfiffner, L. J., \& Barkley, R. A. (1990). Educational placement and classroom management. In $\mathrm{R}$. A. Barkley (Ed.), Attention deficit hyperactivity disorder: A handbook for diagnosis and treatment (pp. 498-539). New York: Guilford.

Pokrivčáková, S. (2015). Teaching foreign languages to learners with special educational needs in Slovakia. Teaching Foreign Languages to Learners with Special Educational Needs, 7-28. doi: 10.17846/ sen.2015.7-28

Reiersen, A. M., Constantino, J. N., \& Todd, R. D. (2008). Co-occurrence of motor problems and autistic symptoms in attention-deficit/hyperactivity disorder. Journal of the American Academy of Child \& Adolescent Psychiatry, 47(6), 662-672.

Richards, J. C. (2005). Communicative language teaching today (pp. 22-26). Singapore: SEAMEO Regional Language Centre.

Richards, Jack C., (2002). Longman Dictionary of Language Teaching and Applied Linguistics. London, New York: Longman.

Saloviita, T. (2015). Measuring pre-service teachers' attitudes towards inclusive education: Psychometric properties of the TAIS scale. Teaching and Teacher Education, 52, 66-72.

Sayal, K., Prasad, V., Daley, D., Ford, T., \& Coghill, D. (2018). ADHD in children and young people: prevalence, care pathways, and service provision. The Lancet Psychiatry, 5(2), 175-186.

Shinn, M. R., Ramsey, E., Walker, H. M., Stieber, S., \& O’Neill, R. E. (1987). Antisocial behavior in school settings: Initial differences in an at risk and normal population. The Journal of Special Education, 21(2), 69-84.

Talmor, R., Reiter, S., \& Feigin, N. (2005). Factors relating to regular education teacher burnout in inclusive education. European Journal of Special Needs Education, 20(2), 215-229. doi:10.1080/08856250500055735.

The United Nations Convention on the Rights of the Child - UNICEF UK. (1989). Retrieved February 17, 2020, from https://www.unicef.org.uk/rightsrespecting-schools/the-rrsa/introducing-the-crc/

Thuneberg, H., Hautamäki, J., Ahtiainen, R., Lintuvuori, M., Vainikainen, M.-P., \& Hilasvuori, T. (2013). Conceptual change in adopting the nationwide special education strategy in Finland. Journal of Educational Change, 15(1), 37-56. doi:10.1007/ s10833-013-9213-x

Torres, L. T. (2016). The Perceptions of Pre-Service Special- and General-Education Teachers on the Inclusion of Children with Special Needs in the Regular Clasroom. Missing information here.

UNESCO. (1976). International Standard Classification of Education (ISCED). Paris: UNESCO.

Vaughn, S., \& Bos, C. S. (2015). Strategies for teaching students with learning and behavior problems (9th ed.). New York: Pearson.

Vietnam's Ministry of Education and Training. (2018a). Circular on inclusive education provided for person with disabilities. Retrieved February 17, 2020, from https://thuvienphapluat.vn/van-ban/giao-duc/ Thong-tu-03-2018-TT-BGDDT-quy-dinh-ve-giaoduc-hoa-nhap-doi-voi-nguoi-khuyet-tat-376274. aspx

Vietnam's Ministry of Education and Training. (2018b). Chương trình môn Tiếng Anh. Chương trình giáo dục phổ thông.

Vietnam's National Assembly. (2010). Luật người khuyết tật. Retrieved February 17th, 2020, from http://vanban.chinhphu.vn/portal/page/ portal/chinhphu/hethongvanban?class_id $=1 \&$ page $=1 \&$ mode $=$ detail\&document_id $=96045$

Vietnam's National Assembly. (2019). Luật phổ cập giáo duc tiểu hoc. Retrieved February 2nd, 2020 from https://luatvietnam.vn/linh-vuc-khac/luat-56lct-hdnn8-quoc-hoi-2178-d1.html

Widdowson, G. H. (2001). Aspects of Language Teaching. Oxford: Oxford University Press.

Zentall, S. S. (1993). Research on the educational implications of attention deficit hyperactivity disorder. Exceptional Children, 60, 143-153. 


\title{
NHŨ̉NG KỸ THUẬT QUẢN LÝ LỚP HỌC TIẾNG ANH THEO MÔ HİNH GIÁO DỤC HÒA NHẬP CHO HỌC SINH TIỂU HỌC MẮC CHÚNG RỐI LOẠN TĂNG ĐỘNG GIẢM CHÚ Ý VÀ RỐI LOẠN PHỔ TỬ KỈ
}

\author{
Vũ Hải Hà, Nguyễn Nhã Uyên \\ Khoa Su phạm tiếng Anh, \\ Truờng Đại học Ngoại ngũu, Đại học Quốc gia Hà Nội \\ Phạm Văn Đồng, Cầu Giấy, Hà Nội, Việt Nam
}

Tóm tắt: Nhận ra tầm quan trọng của tiếng Anh như một ngôn ngữ thiết yếu trong giao tiếp toàn cầu hóa, Việt Nam đã đưa ngôn ngữ này trở thành môn học bắt buộc trong chương trình giáo dục phổ thông từ lớp ba. Do đó, việc giảng dạy tiếng Anh cho trẻ em dần trở thành vấn đề thu hút được sự quan tâm của các nhà giáo dục và các nhà nghiên cứu. Tuy nhiên, đối tượng trẻ mắc rối loạn tăng động giảm chú ý và rối loạn phổ tự kỉ, hai dạng rối loạn tâm thần thường gặp nhất ở trẻ em, lại chưa nhận được nhiều sự quan tâm. Vì những lý do đó, nghiên cứu trường hợp điển hình theo đường hướng tiếp cận hỗn hợp này được thực hiện nhằm khảo sát những khó khăn mà giáo viên tiếng Anh tiểu học gặp phải, cũng như những giải pháp khắc phục mà họ đã sử dụng để quản lý một lớp học có những học sinh mắc chứng rối loạn nói trên trong mô hình hòa nhập. Sau khi điều tra và thu được 109 phiếu trả lời từ 20 thành phố thuộc ba miền trên cả nước, nghiên cứu tiếp tục phỏng vấn sâu với giáo viên kết hợp với quan sát lớp học để rút ra kết luận. Kết quả nghiên cứu cho thấy giáo viên gặp nhiều khó khăn, trong đó khó khăn lớn nhất là sự bất đồng trong giao tiếp với phụ huynh trẻ rối loạn. Ngoài ra, giáo viên có thể xây dựng những kỹ thuật dạy học thể hiện sự sáng tạo và linh hoạt cao để quản lý lớp học, dù vẫn còn sự xuất hiện của một vài hành vi chưa chuyên nghiệp xuất phát từ việc giáo viên hiếm khi được đào tạp về giáo dục đặc biệt. Nhờ đó, bài báo này có thể là một nguồn tham khảo có giá trị dành cho những giáo viên và nhà nghiên cứu làm việc với trẻ rối loạn tăng động giảm chú ý và rối loạn phổ tự kỉ tại Việt Nam.

Tù khóa: Rối loạn tăng động giảm chú ý, Rối loạn phổ tự kỉ, quản lý lớp học, tiểu học, Việt Nam 